\title{
ANTIVIRAL SYSTEM OF INNATE IMMUNITY: COVID-19 PATHOGENESIS AND TREATMENT
}

\author{
Kazimirskii AN $\bowtie$, Salmasi JM, Poryadin GV
}

Pirogov Russian National Research Medical University. Moscow, Russia

Antiviral system of innate immunity includes two main components: the mitochondrial antiviral sensor - the mitochondrial outer membrane protein and peripheral blood neutrophils capable of forming neutrophilic extracellular traps. Depending on the activation pathway of the mitochondrial antiviral sensor (MAVS), two possible variants of cells death, apoptosis or cellular degeneration with necrotic changes, develop during cell infection with an RNA-containing virus. The development of virus-induced apoptosis of infected cells causes the formation of neutrophilic extracellular traps, the secretion of inflammatory cytokines, ROS generation, tissue damage, hemocoagulation and the development of an acute inflammatory process with the development of COVID-19 pneumonia. Violation of the prion-like reaction of MAVS in response to viral infection of the cell triggers an alternative pathway for activating autophagy. Cells under conditions of prolonged activation of autophagy experience necrotic changes and are eliminated from the organism by monocytes/macrophages that secrete anti-inflammatory cytokines. This type of reaction of the antiviral system of innate immunity corresponds to the asymptomatic course of the disease. From the most significant aspects of the pathogenesis of the coronavirus infection COVID-19 given, recommendations for the prophylactic treatment of this dangerous disease follow. The proposed treatment can significantly decrease the severity of COVID-19 disease and reduce mortality.

Keywords: innate immunity, antiviral system, mitochondrial antiviral signaling protein, MAVS, neutrophilic extracellular traps, COVID-19 treatment

Author contribution: the authors contributed equally to all aspects of the article.

$\triangle$ Correspondence should be addressed: Alexander N. Kazimirskii Ostrovityanova, 1, Moscow, 117437; alnica10@mail.ru

Received: 31.08.2020 Accepted: 13.09.2020 Published online: 21.09.2020

DOI: 10.24075/brsmu.2020.054

\section{АНТИВИРУСНАЯ СИСТЕМА ВРОЖДЕННОГО ИММУНИТЕТА: ПАТОГЕНЕЗ И ЛЕЧЕНИЕ COVID-19}

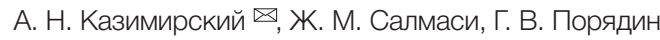

Российский национальный исследовательский медицинский университет имени Н. И. Пирогова, Москва, Россия

\begin{abstract}
В обзоре представлена концепция антивирусной системы врожденного иммунитета и описаны главные структурные компоненты этой системы в организме человека, действующей против РНК-содержащих вирусов. Антивирусная система врожденного иммунитета включает в себя два главных компонента: митохондриальный антивирусный сенсор (MAVS) - белок наружной мембраны митохондрий и нейтрофилы периферической крови, способные формировать нейтрофильные экстраклеточные ловушки. В зависимости от пути активации MAVS при инфицировании клетки РНК-содержащим вирусом развиваются два возможных варианта ее гибели - апоптоз или дегенерация клеток с некротическими изменениями. Развитие вирус-индуцированного апоптоза инфицированных клеток вызывает формирование нейтрофильных экстраклеточных ловушек, секрецию воспалительных цитокинов, генерацию AФК, тканевое повреждение, гемокоагуляцию и возникновение острого воспалительного процесса с развитием COVID-19-пневмонии. Нарушение прионоподобной реакции MAVS в ответ на вирусное инсицирование клетки запускает альтернативный путь активации аутофагии. Клетки в условиях продолжительной активации аутофагии испытывают дегенеративные изменения и элиминируются из организма моноцитами/макрофагами, которые секретируют противовоспалительные цитокины. Такой тип реакции антивирусной системы врожденного иммунитета соответствует бессимптомному течению заболевания. Из приведенных наиболее существенных сторон патогенеза коронавирусной инфекции COVID-19 вытекают рекомендации по профилактическому лечению этого опасного заболевания. Предлагаемое лечение позволит значительно ослабить тяжесть заболевания Соvid-19 и снизить летальность.
\end{abstract}

Ключевые слова: врожденный иммунитет, антивирусная система, митохондриальный антивирусный сигнальный белок, MAVS, нейтрофильные экстраклеточные ловушки, лечение COVID-19

Вклад авторов: равнозначный

$凶$ Для корреспонденции: Александр Николаевич Казимирский

ул. Островитянова, д. 1, г. Москва, 117437, alnica10@mail.ru

Статья получена: 31.08.2020 Статья принята к печати: 13.09.2020 Опубликована онлайн: 21.09.2020

DOI: $10.24075 /$ vrgmu.2020.054

In the past 20 years, eight new deadly viruses have been discovered that threaten humans, which actualized the search for components of the organism's antiviral system. Several studies have shown that the antiviral system of the human organism is associated with innate immunity and it activates immediately when the virus enters into the human cells, so it can be called the antiviral system of innate immunity.

The existence of the antiviral system of innate immunity is recognized by some researchers, but both the components of this system and its functioning are still unclear. At the same time, the accumulated experimental material allows us to identify the main parts of this system and create a model of its functioning. In no case do we claim to fully cover this issue, but we suppose that the antiviral system of innate immunity has two main components: the mitochondrial antiviral sensor — the outer membrane protein of mitochondrion and neutrophils that can form neutrophilic extracellular traps.

\section{Mitochondrial antiviral sensor}

Mitochondrial antiviral sensor (mitochondrial antiviral signaling protein, MAVS) - a surface protein of the outer mitochondrial membrane with prion-like activity has the ability to change conformation when interacting with viral RNA. Viral infection triggers the formation of aggregates of mitochondrial antiviral signaling protein (MAVS), which actively stimulates immune signaling [1]. The antiviral effect of this protein depends on the speed of its renewal. The weakening of the immune response 
and increased intracellular infection is due to the inhibition of ubiquitin ligase, which is responsible for the accelerated renewal of MAVS [2]. Mutations in MAVS that disrupt its prion-like activity also completely cancel its ability to transmit immune activation signals in mammalian cells. The results of some studies show that prion-like polymerization is a conservative mechanism of signal transmission of activation of innate immunity even in the development of inflammation [3, 4]. The importance of mitochondrial antiviral signaling protein (MAVS) has been demonstrated in the infection of wild-type mice with Ebola virus (EBOV). MAVS controlled EBOV replication through IFN $\alpha$ expression, impaired inflammatory responses in the spleen, and prevented liver cell death. MAVWS (-/-) mice developed severe inflammation, viral replication, and decreased IFN-I synthesis [5]. The threat, associated with Zika virus epidemics (ZIKV) and its association with serious complications, confirms the need for a better understanding of ZIKV pathogenic mechanisms. Examining RNA sequencing in the blood of patients infected with ZIKV, it was found that programs of transcriptional antiviral interferon-stimulated genes and innate immune sensors in patients infected with ZIKV remained inactive compared to those in healthy donors. In infected patients, ZIKV was able to suppress the induction of IFN-I, and the viral protein ZIKV NS4A bound MAVS and thereby interrupted the interaction of RIG-I/ MAVS reducing the synthesis of INF-I [6]. Some extracellular pathogens can activate intracellular defense mechanisms against viral infections. Pneumolysin (Ply), the main virulence factor of Streptococcus pneumoniae, is able to initiate oxidative damage to mitochondria, which causes the release of mitochondrial DNA, which mediates the expression of IFN $\beta$ in macrophages. In response to pneumolysin, macrophages express IFN $\beta$ using an interferon gene stimulator STING (stimulator of interferon genes) [7]. The activation of the main intracellular adapter proteins of the antiviral defense MAVS and STING consists in their phosphorylation with the participation of certain (serine-threonine) protein kinases (IKK and/or TBK1) when pathogens enter the cell [8]. An intracellular signal of cell infection is an unusual noncanonical cyclic dinucleotide 2'3'-cGAMP (cGAMP) [9]. The organism of higher mammals and humans synthesizes the cyclic guanyl-adenyl dinucleotide 2'3'-cGAMP capable of activating the main intracellular adapter antiviral defense proteins MAVS and STING under the influence of the enzyme cGAMP synthase. The formation of 2 ' 3 '-cGAMP is catalyzed by cGAMP synthase (cGAS) when a cytosolic double-stranded DNA is detected and functions as an endogenous inducer of innate immunity by directly binding and activating an adapter protein, an interferon gene stimulator (STING). This cyclic 2'3'-cGAMP dinucleotide stimulates the secretion of interferon- $\beta$ (IFN $\beta$ ), a major defense signaling pathway that is independent of activation of innate immunity receptors (toll-like receptors, TLRs) [10]. The Vaccinia virus in human cells induces the synthesis of specific nucleases called poxins capable of catalyzing the cleavage of the $3^{\prime}-5^{\prime}$ bond, converting the cyclic 2',3'-cGAMP into a linear Gp[2' 5']Ap[3'] dinucleotide. Linear guanyl-adenyl dinucleotide loses its ability to activate the interferon gene stimulator (STING), while the antiviral mechanisms do not work. The results demonstrate the mechanism by which viruses avoid innate immunity [11].

In the recognition of intracellular pathogens and the production of interferons I, (IFN-I), the most important role belongs to dendritic cells and macrophages [12]. When mice were infected with respiratory syncytial virus (RSV), which is the most common cause of respiratory infections in infants and young children, alveolar macrophages were identified as the main source of IFN-I [13]. Infection of genetically modified Myd88/Trif/Mavs (-/-) mice in which signaling was impaired by all TLR, RLR (RIG-I, MDA5, LGP2) and IL-1R, as well as other cytokine receptors, such as IL18 receptor showed that in such RSV-infected animals, the early production of pro-inflammatory mediators was completely absent. However, RSV-specific CD8 ${ }^{+}$T-lymphocytes were observed in lung tissue and airways. RSV-infected Myd88/Trif/Mavs (-/-) mice with disabled innate immunity overcame the infection, but showed higher viral load, severe and prolonged inflammation, and weight loss. These data demonstrate both a certain level of redundancy in the organism's immune defense and the fact that the involvement of cytotoxic T-lymphocytes in the response is provided by cells of the infected tissue itself producing IFNy [14]. In the experimental model of Toxoplasmosis (Toxoplasma gondii), the presence of a non-lymphoid source of IFN $\gamma$ was determined in genetically modified mice with the absence of all lymphoid cells due to deficiencies of recombinant activating genes 2 and $\mathrm{IL}-2 \mathrm{R} \gamma \mathrm{c}$, which also produced IFNy in response to a simple parasite. Flow cytometry and morphological studies showed that in this experimental model, the sources of IFN $\gamma$ are neutrophils, not NK cells and not CD8 $8^{+}$T lymphocytes $[15,16]$. Intracellular pathogens also induce accelerated formation of IFN $\gamma$. Moreover, viral infection does not increase the expression of innate immunity receptors (TLRs) in plasmacytoid dendritic cells. Mice infected with the lymphocytic choriomeningitis virus developed strong TLR-independent production of interferon I (IFN-I) using RNA helicase and with the participation of mitochondrial antiviral signaling protein (MAVS) [17].

\section{MAVS induces apoptosis}

MAVS (IPS-1, VISA or Cardif) is important for protecting the host organism against viral infection not only by inducing interferons-I (IFN-I), but it also causes apoptosis of infected cells regardless of its function in initiating production IFN-I. Moreover, MAVS (-/-) fibroblasts are resistant to apoptosis caused by the Sendai virus. Functional screening shows that severe acute respiratory syndrome coronavirus (SARS-CoV) protein (NSP15) inhibits MAVS-induced apoptosis and this is a method of coronavirus immune evasion [18]. In MAVSdeficient cells, caspase- 8 and -3 activation are reduced. After infection with the RNA virus, MAVS induces type I antiviral response and recruits caspase- 8 in mitochondria to ensure activation of caspase-3 and apoptosis of infected cells [19]. African swine fever virus increases MAVS expression in alveolar macrophages. MAVS expression was enhanced by intracellular reactive oxygen species (ROS). In addition, MAVS increased the induction of antiviral and proinflammatory cytokines and apoptosis of infected cells and inhibited virus replication [20].

In mice with MAVS deficiency, hepatitis A virus causes histological signs of liver damage, leukocyte infiltration, and the release of liver enzymes into the blood [21]. The miR-33/33* miRNA was found to be able to increase viral replication and mortality, while at the same time weakening the synthesis of interferon-I in vitro and in vivo. Further studies showed that this miRNA prevents the formation of activated aggregates of mitochondrial antiviral signal protein (MAVS) and is a negative regulator of the antiviral system of innate immunity [22]. These and several other studies show the critical role of mitochondrial antiviral signaling protein (MAVS) in virus-induced apoptosis. Viral infection triggers the organism's defense mechanisms, the main of which is the mitochondrial antiviral sensor. The antiviral defense strategy of the organism is to initiate apoptosis of cells infected with RNA-containing viruses. The described protection 
strategy can only be implemented with a functionally complete MAVS.

\section{Inhibition of inflammation by reducing the number of apoptotic cells}

After synthesis in the cell and its transport into the outer mitochondrial membrane, the mitochondrial antiviral sensor undergoes modification over time. The essence of the modification of this viral RNA sensor is its geranylation (addition of two residues of geranyl diphosphate) followed by palmitoylation (addition of two residues of palmitic acid). Such a modified mitochondrial antiviral sensor is not capable of aggregation under the influence of viral RNA and is not capable of activation and aggregation with the subsequent development of apoptosis of the virus of the infected cell [23]. Geranyl diphosphate is a linear ten-carbon molecule consisting of two isoprene residues formed in the organism in the way of cholesterol synthesis, therefore, preventive treatment of coronavirus infection may consist in pharmacological inhibition of the cholesterol synthesis pathway using statins. The timely use of preventive therapy against coronavirus infection (COVID-19) will help to avoid the severe course of the disease and the development of complications. The inflammatory process, with a functionally complete mitochondrial antiviral sensor, as we assume, will be localized in the upper respiratory tract and will not be spread in the organism. An important and relevant question about predicting the severity, complications and outcome of a coronavirus infection can be resolved after developing a test for the presence of a geranylated mitochondrial antiviral sensor. Uninfected people with a high level of modified (geranylated) MAVS may be at risk for coronavirus infection (SARS-CoV-2) and need in isolation and prescribing prophylactic therapy.

\section{Neutrophilic extracellular traps}

Neutrophilic extracellular traps are a form of response of preactivated neutrophils to contact interactions with cells in a state of apoptosis. Neutrophils are pre-activated by receiving activation signals through various innate immunity receptors (TLRs). At the activation stage, neutrophils interact with various molecules of pathogens or modified molecules in our organism that recognize innate immunity receptors (TLRs) as pathogens. During the activation of neutrophils, occurs the expression of the genome, the synthesis of cytokines and enzymes, the generation of reactive oxygen (ROS) and nitrogen (NOS) species. However, this is not enough for the formation of neutrophilic extracellular traps.

Disclosure of neutrophilic extracellular traps occurs after interaction with apoptotic cells or their residues. A network of neutrophilic DNA fibers captures and holds apoptotic cells, and then other intact neutrophils and monocytes phagocytose this structure, hydrolyzing its components and presenting antigens. Interestingly, after phagocytosis, cells are no longer capable of opening neutrophilic extracellular traps [24-27]. A signal molecule that causes activated neutrophils to form neutrophilic extracellular traps is a membrane lipid phosphatidylserine located on the surface of apoptotic cells. The development of cell apoptosis is associated with the inversion of the membrane lipid phosphatidylserine - normally located on the inner surface of the cell membrane. Phosphatidylserine is transferred from the inner cell membrane to the outer surface using phospholipid scramblase-1 (PLSCR1) and is an apoptotic signal for neutrophil activation with the opening of neutrophilic extracellular traps [26].
Excessive formation of neutrophilic extracellular traps causes hemocoagulation

The effect of phosphatidylserine on activated neutrophils is a key event in the pathogenesis of microvascular dysfunction. Studies have revealed a previously unrecognized relationship between hypercoagulation and the presence of phosphatidylserine in the blood, which causes a risk of thrombosis [28, 29]. Thrombotic complications are a serious danger in many diseases. Since the discovery of neutrophilic extracellular traps, the view on the pathophysiology of thrombosis has changed significantly. Networks generated by neutrophils, which consist of decondensed chromatin in the form of fibers, contribute to the formation of a blood clot, serving as a framework that activates platelets and coagulation. Thrombogenic vascular damage caused by excessive formation of neutrophilic extracellular traps has been described under various conditions of thrombosis, including stroke, myocardial infarction, and deep vein thrombosis [30]. To overcome thrombogenic vascular damage, it was proposed to use DNase I, which will limit the excessive formation of decondensed chromatin fibers and accelerate their hydrolysis [31]. The mechanisms underlying the development of systemic coagulopathy and acquired thrombophilia, characterized in most cases by a tendency to venous, arterial and microvascular thrombosis in COVID-19 pandemics, are unclear. Doctors and researchers are at the stage of collecting and analyzing information about this dangerous infection [32].

In the pathogenesis of coronavirus infection (COVID-19), there is a clear connection between the development of systemic coagulopathy and the formation of neutrophilic extracellular traps. Moreover, the most clinically severe patients are those who develop virus-induced apoptosis, only in some infected cells. These cells express phosphatidylserine on the surface and induce the neutrophilic extracellular traps formation that traps apoptotic cells and their residues. Another part of infected cells does not enter apoptosis due to functional deficiency of the mitochondrial antiviral sensor. These cells are involved in viral replication and support the spread of the virus throughout the human organism. The spread of the virus throughout the organism increases the number of apoptotic cells and, accordingly, the number of revealing neutrophilic extracellular traps. During the formation of extracellular traps, neutrophils secrete proinflammatory cytokines, enzymes, ROS, and peptides with pore-forming activity. Parts of the secreted products - ROS, peptides with pore-forming activity (such as LL-37), TNF $\alpha$ are designed to damage and destroy microorganisms. But in the absence of a bacterial infection, their own tissues and blood cells are damaged. Endothelial cells of capillaries of the pulmonary circulation become porous, which leads to interstitial pulmonary edema, the development of viral pneumonia, and an increase in the permeability of erythrocyte and platelet membranes causes hemoglobin loss and hemocoagulation. Our concept is supported by studies of patients with COVID-19 pneumonia, in which neutrophilic extracellular traps were found in microvessels of the pulmonary circulation together with damaged endothelial cells and fibrin deposits [33].

\section{Development of immunodeficiency in patients with coronavirus infection}

The study of blood cells in patients with severe coronavirus infection (COVID-19) showed that they have a reduced number of lymphocytes and an increased number of leukocytes. The 
total number of T-lymphocytes was significantly reduced due to both $\mathrm{CD}^{+}$and $\mathrm{CD}^{+}$cells compared with the level of healthy donors [34]. Moreover, the degree of developing immunodeficiency depends on the severity and duration of the disease. Prolonged infectious inflammation causes significant changes in the population and subpopulation of T-lymphocytes, and causes the development of T-cell immunodeficiency. The decrease in the content of T-lymphocytes, as well as a subpopulation of peripheral blood $\mathrm{CD}^{+}$and $\mathrm{CD}^{+}$cells, is based on an insufficient expression of lymphocyte activation antigens (CD25, CD71, HLA-DR) and increased expression of activation apoptosis trigger receptor CD95 [35-37]. The action of these factors cause accelerated elimination of T-lymphocytes and cause the development of immunodeficiency. These observations indicate that the treatment strategy for patients should be aimed at reducing the time of inflammation.

\section{Violations of lgG synthesis in patients with coronavirus infection}

The formation of immunity in coronavirus infection (COVID-19) is an almost insoluble problem for doctors and researchers. Without a detailed analysis of the results of screening for antibodies in patients after a coronavirus infection, the main features of the deficiency in the formation of immunoglobulins can be identified. This is, first of all, the absence of virus-specific lgG in some patients, a low titer of virus-specific lgG, and in some patients, an extremely weakened immune response, which nevertheless causes the formation of a virus-specific IgG, but in some cases this occurs only after 4-5 or more weeks after admission to the hospital. Thus, it was reported that five of the six examined patients had a high titer of virus neutralizing antibody [38]. Examination of 208 plasma samples 14 days after the onset of the disease revealed the presence of virus-specific lgM and IgG in $85.4 \%$ and $77.9 \%$ of patients, respectively [39]. Being unable to analyze the obtained data, the authors cite a set of separate observations, from which it follows that virus-specific IgM and IgG antibodies in individual patients were recorded $6,11,18,23,24,35$, and 43 days after admission to the intensive care unit. As can be seen from the data provided, the late period for the appearance of specific IgG coincides with a higher viral load of patients [40]. The results of the studies showed that coronavirus infection (SARSCoV-2) is accompanied by obvious violations of the production of specific immunoglobulins and this is the main mechanism of immunopathogenesis. The cause for the observed violations may be related to the excessive formation of neutrophilic extracellular traps during coronavirus infection. The formation of a network of DNA fibers is accompanied by the secretion of a number of compounds, including the secretion of enzymes. The main secreted enzymes are NADPH oxidase, myeloperoxidase, arginase. The physiological significance of NADPH oxidase, myeloperoxidase has been established and consists in the generation of reactive oxygen and nitrogen species that damage and inactivate various pathogens. The role of arginase is to disrupt antigenic presentation by antigen-presenting cells and inhibit $\mathrm{T}$ cells with helper induction function (CD4 ${ }^{+}$ cells) in the initial period of inflammation. The role of arginase in inhibiting adaptive immunity has been described previously [41]. Investigating the early stages of inflammation, found pronounced reciprocity in relation to the activation of innate and adaptive immunity. The physiological role of arginase secreted by neutrophils is to organize the correct and consistent activation of two parts of the immune system [42, 43]. However, prolonged inflammation is dangerous not only by damage to one's own tissues, but also by the development of hemocoagulation. As can be seen, there is a pronounced prolonged suppression of adaptive immunity, the result of which is the insufficient formation of virus-specific immunoglobulin in some patients.

A feature of coronavirus infection (COVID-19) is that damaged endothelial cells of the capillaries of the pulmonary circulation also contain arginase. Therefore, with inflammation accompanying a coronavirus infection, arginase enters the blood from two sources - neutrophils and endothelial cells. The suppression of adaptive immunity in this infection is especially pronounced. Overcoming the inhibition of adaptive immunity in patients in order to activate immunogenesis can be achieved, in our opinion, by the use of arginase inhibitors (like valine) in the acute period of the disease.

\section{Asymptomatic coronavirus infection}

A number of patients with coronavirus infection have an asymptomatic course. The danger is that asymptomatic virus carriers can infect other people. They can also be reinfected. So, 38 out of 112 COVID-19 positive patients have an asymptomatic course of the disease, while lgM antibodies were detected in 22 patients, 7 patients in this group had IgG antibodies, and 9 patients did not have virus-specific antibodies [44]. A group of 24 asymptomatic carriers of the SARS-CoV-2 virus was described. After hospitalization, in five cases (20.8\%) symptoms appeared (fever, cough, fatigue), in twelve cases (50.0\%) typical frosted glass images were found on CT scans, and in 5 (20.8\%) observed bands of dimming in the lungs. No severe pneumonia was detected. None of the 24 cases revealed severe pneumonia. But in some family members of these asymptomatic carriers, severe coronavirus pneumonia was subsequently detected [45]. A study of the spread of coronavirus infection among recruits of the Swiss Armed Forces in the canton of Ticino (southern canton of Switzerland on the border with Italy) shows that young healthy people often show a moderate course of COVID-19 with a rapid alleviation of symptoms, but they were constant carriers of SARS-CoV-2 [46].

\section{Asymptomatic course of the disease - activation of an alternative way to remove the virus from the organism}

The asymptomatic course of COVID-19 disease is associated with activation of autophagy. Autophagy consists in the renewal of many cellular structures and is activated when the cell enters stressful conditions. At the same time, it is also a way to overcome viral infection due to accelerated hydrolysis of cellular proteins and other components with their subsequent synthesis. Autophagy is one of the first lines of cellular defense against the invasion of microorganisms, including viruses [47]. Many viruses have evolved to the point that they use autophagy for their own development. They acquired the ability to either inhibit autophagy in the cell, escaping the cellular hydrolysis of their components or, which is more common, to use autophagosomes for replication and assembly of viral particles. Moreover, some viruses can even cause additional activation of autophagy in an infected cell for their own development. Thus, Picornaviruses use the cell apparatus for reproduction, and then inhibit the fusion of autophagosomes with lysosomes, which leads to an increase in the formation of viral particles [48]. Enterovirus A71 (EV-A71) activates autophagy both in vitro and in vivo. EV-A71 triggers the formation of autolysosomes during infection in human rhabdomyosarcoma cells, which facilitates its replication [49]. Zika virus (ZIKV), upon infection of human umbilical vein endothelial cells, triggers cell autophagy 
Table. The reaction of the antiviral system of innate immunity and the organism's inflammatory response

\begin{tabular}{|l|c|c|c|c|}
\hline $\begin{array}{c}\text { Cell response to infection } \\
\text { with an RNA-containing virus }\end{array}$ & MAVS reaction & Mononuclear blood cells & $\begin{array}{c}\text { Characterization of the } \\
\text { inflammatory process }\end{array}$ \\
\hline Apoptosis & $\begin{array}{c}\text { MAVS induces prion-like } \\
\text { polymerization }\end{array}$ & $\begin{array}{c}\text { Activated neutrophils form } \\
\text { neutrophilic extracellular traps }\end{array}$ & Pro-inflammatory & Acute inflammatory process \\
\hline $\begin{array}{l}\text { Cellular degeneration with } \\
\text { necrotic changes }\end{array}$ & $\begin{array}{c}\text { MAVS does not induce } \\
\text { prion-like polymerization }\end{array}$ & $\begin{array}{c}\text { Activated neutrophils do not form } \\
\text { neutrophilic extracellular traps }\end{array}$ & Anti-inflammatory & $\begin{array}{c}\text { No signs of inflammation, } \\
\text { asymptomatic course of the } \\
\text { disease }\end{array}$ \\
\hline
\end{tabular}

and enhances replication using autophagosomes. The use of inhibitors of autophagosome formation significantly reduces the formation of viral particles [50, 51]. Uzutu virus (USUV) is an African mosquito-borne flavivirus that is closely associated with West Nile fever virus and Japanese encephalitis virus, the carriers of which are mainly mosquitoes and birds. The presence of USUV in Africa was discovered more than 50 years ago, but in the last decade it has appeared in Europe, causing episodes of bird mortality and some cases of serious illness among people. USUV infection also stimulates autophagy. Pharmacological modulation of the autophagy pathway using the autophagy inducer Rapamycin led to an increase in the output of the virus. On the other hand, treatment with 3-methyladenine or Wortmannin, two different phosphatidylinositol-3-kinase inhibitors involved in autophagy, reduced the output of viral particles [52].

RIG-I (retinoic acid-inducible gene 1), which detects viral infections by recognition of viral RNA, MAVS and TRAF6 (TNF receptor-associated factor 6), a cytosolic adapter protein belonging to the family of factors related with TNF alpha receptor, takes part in virus-induced autophagy. Deficiency in the cells of any of these proteins disrupts the initiation of autophagy [53]. These and many other studies have shown that viruses circulating among the human population for a long time, use autophagy mechanisms for their own development. SARS-CoV-2 apparently does not yet have such mechanisms. Despite the fact that direct data on the interaction of SARSCoV-2 with autophagy proteins or autophagosomes have not been obtained, however, the nature of the asymptomatic course of COVID-19 indicates that autophagy in this disease nevertheless fulfills its deterrent role and prevents the spread of the virus in the human organism.

\section{Activation of autophagy causes cellular degeneration of virus infected cells}

Short-term activation of autophagy promotes cell survival with insufficient intake of the necessary metabolites. Activation of virus-induced autophagy continues for a long time and leads to cellular degeneration and necrotic cell death [54-57]. Such cells do not exhibit phosphatidylserine on their surface and therefore are not able to cause the neutrophilic extracellular traps formation.

Therefore, secretion of inflammatory cytokines does not occur. Removal of such infected cells develops through phagocytosis by monocytes/macrophages secreting antiinflammatory cytokines. The asymptomatic course of the disease is due to the reaction of the antiviral system of innate immunity in an alternative way. The results of the study are presented in the table.
The polarization of M0 macrophages into M2 phenotype producing anti-inflammatory cytokines develops with IFNy deficiency, and in the presence of IFN $\gamma$, the differentiation of macrophages in $M 2$ phenotype is weakened [58, 59], which explains the presence of anti-inflammatory cytokines in case of formation of neutrophilic extracellular traps.

The treatment strategy for asymptomatic COVID-19 patients may be directed to the activation of apoptosis in cells infected with the virus. For this, Resveratrol can be used, which is able to induce apoptosis, while inhibiting the anti-apoptotic protein $\mathrm{Bcl} 2$, and enhancing the expression of p53 in normal and tumor human cells [60-62].

We call on doctors and researchers to experimentally verify the theoretical basis of our concept and the treatment methods of COVID-19 resulting from our proposed antiviral system of innate immunity.

\section{CONCLUSION}

The data presented in this article allow us to describe the components and functioning of the antiviral system of innate immunity in the human organism. We suggest that the antiviral system of innate immunity has two main components: the mitochondrial antiviral sensor - the mitochondrial outer membrane protein and peripheral blood neutrophils capable of forming neutrophilic extracellular traps. Depending on the activation pathway of the mitochondrial antiviral sensor (MAVS), when a cell is infected with an RNA-containing virus (SARSCoV-2), two possible variants of its death, apoptosis or cellular degeneration with necrotic changes develop. These variants of the predominant cell death determine the type of inflammation and the course of the disease. The development of virus-induced apoptosis of infected cells causes the formation of neutrophilic extracellular traps, the secretion of inflammatory cytokines, ROS generation, tissue damage, hemocoagulation and the development of an acute inflammatory process in the form of COVID-19 pneumonia. Violation of the prion-like reaction of MAVS in response to viral infection of the cell triggers an alternative pathway for the activation of autophagy. Cells under conditions of prolonged activation of autophagy experience necrotic changes and are eliminated from the organism by monocytes/macrophages that secrete anti-inflammatory cytokines. This type of reaction of the antiviral system of innate immunity corresponds to the asymptomatic course of the disease.

The given main stages of the pathogenesis of coronavirus infection make it possible to propose pathogenetically substantiated therapy that can significantly reduce the severity of the disease, activate immunity and reduce mortality. 
1. Cai X, Xu H, Chen ZJ. Prion-Like Polymerization in Immunity and Inflammation. Cold Spring Harb Perspect Biol. 2017; 9 (4). pii: a023580. DOI: 10.1101/cshperspect.a023580.

2. He X, Zhu Y, Zhang Y, Geng Y, Gong J, Geng J, et al. RNF34 functions in immunity and selective mitophagy by targeting MAVS for autophagic degradation. EMBO J. 2019. pii: e100978. DOI: 10.15252/embj.2018100978.

3. Cai X, Chen J, Xu H, Liu S, Jiang QX, Halfmann R, et al. Prion-like polymerization underlies signal transduction in antiviral immune defense and inflammasome activation. Cell. 2014; 156 (6): 12072. DOI: 10.1016/j.cell.2014.01.063.

4. Cai X, Xu H, Chen ZJ. Prion-Like Polymerization in Immunity and Inflammation. Cold Spring Harb Perspect Biol. 2017; 9 (4). pii: a023580. DOI: 10.1101/cshperspect.a023580.

5. Dutta M, Robertson SJ, Okumura A, Scott DP, Chang J, Weiss JM, et al. A Systems Approach Reveals MAVS Signaling in Myeloid Cells as Critical for Resistance to Ebola Virus in Murine Models of Infection. Cell Rep. 2017; 18 (3): 816-29. DOI: 10.1016/j. celrep.2016.12.069.

6. Hu Y, Dong X, He Z, Wu Y, Zhang S, Lin J, et al. Zika virus antagonizes interferon response in patients and disrupts RIGI-MAVS interaction through its CARD-TM domains. Cell Biosci. 2019; 9: 46. DOI: 10.1186/s13578-019-0308-9. eCollection 2019.

7. Hu X, Peng X, Lu C, Zhang X, Gan L, Gao Y, et al. Type I IFN expression is stimulated by cytosolic MtDNA released from pneumolysin-damaged mitochondria via the STING signaling pathway in macrophages. FEBS J. 2019. DOI: 10.1111/febs.15001.

8. Liu S, Cai X, Wu J, Cong Q, Chen X, Li T, et al. Phosphorylation of innate immune adaptor proteins MAVS, STING, and TRIF induces IRF3 activation. Science. 2015; 347 (6227): aaa2630. DOI: 10.1126/science.aaa2630.

9. Diner EJ, Burdette DL, Wilson SC, Monroe KM, Kellenberger CA, Hyodo $\mathrm{M}$, et al. The innate immune DNA sensor cGAS produces a noncanonical cyclic dinucleotide that activates human STING. Cell Rep. 2013; 3 (5): 1355-61. DOI: 10.1016/j.celrep.2013.05.009.

10. Schwede F, Genieser HG, Rentsch A. The Chemistry of the Noncanonical Cyclic Dinucleotide 2'3'-cGAMP and Its Analogs. Handb Exp Pharmacol. 2017; 238: 359-84. DOI: 10.1007/164_2015_43.

11. Eaglesham JB, Pan Y, Kupper TS, Kranzusch PJ. Viral and metazoan poxins are cGAMP-specific nucleases that restrict cGAS-STING signalling. Nature. 2019; 566 (7743): 259-63. DOI: 10.1038/s41586-019-0928-6.

12. Oh DS, Kim TH, Lee HK. Differential Role of Anti-Viral Sensing Pathway for the Production of Type I Interferon - in Dendritic Cells and Macrophages Against Respiratory Syncytial Virus A2 Strain Infection. Viruses. 2019; 11 (1). pii: E62. DOI: 10.3390/ v11010062.

13. Goritzka M, Makris S, Kausar F, Durant LR, Pereira C, Kumagai $Y$, et al. Alveolar macrophage-derived type I interferons orchestrate innate immunity to RSV through recruitment of antiviral monocytes. J Exp Med. 2015 May 4; 212 (5): 699-714. DOI: 10.1084/jem.20140825.

14. Goritzka M, Pereira C, Makris S, Durant LR, Johansson C. T cell responses are elicited against Respiratory Syncytial Virus in the absence of signalling through TLRs, RLRs and IL-1R/IL-18R. Sci Rep. 2015 Dec 21; 5: 18533. DOI: 10.1038/srep18533.

15. Sturge CR, Benson A, Raetz M, Wilhelm CL, Mirpuri J, Vitetta ES, et al. TLR-independent neutrophil-derived IFN- $\gamma$ is important for host resistance to intracellular pathogens. Proc Natl Acad Sci USA. 2013; 110 (26): 10711-6. DOI: 10.1073/pnas.1307868110.

16. Kirsebom FCM, Kausar F, Nuriev R, Makris S, Johansson C. Neutrophil recruitment and activation are differentially dependent on MyD88/TRIF and MAVS signaling during RSV infection. Mucosal Immunol. 2019. DOI: 10.1038/s41385-019-0190-0.

17. Gonzalez-Quintial R, Nguyen A, Kono DH1, Oldstone MBA, Theofilopoulos AN, Baccala R. Lupus acceleration by a MAVSactivating RNA virus requires endosomal TLR signaling and host genetic predisposition. PLoS One. 2018; 13 (9): e0203118. DOl: 10.1371/journal.pone.0203118. eCollection 2018.

18. Lei Y, Moore CB, Liesman RM, O'Connor BP, Bergstralh DT, Chen ZJ, et al. MAVS-mediated apoptosis and its inhibition by viral proteins. PLoS One. 2009; 4 (5): e5466. DOI: 10.1371/journal. pone.0005466.

19. El Maadidi S, Faletti L, Berg B, Wenzl C, Wieland K, Chen ZJ, et al. A novel mitochondrial MAVS/Caspase-8 platform links RNA virus-induced innate antiviral signaling to Bax/Bak-independent apoptosis. J Immunol. 2014; 192 (3): 1171-83. DOI: 10.4049/ jimmunol.1300842.

20. Dong W, Lv H, Li C, Liu Y, Wang C, Lin J, et al. MAVS induces a host cell defense to inhibit CSFV infection. Arch Virol. $2018 \mathrm{Jul}$; 163 (7): 1805-21. DOI: 10.1007/s00705-018-3804-z.

21. Hirai-Yuki A, Whitmire JK, Joyce M, Tyrrell DL, Lemon SM. Murine Models of Hepatitis A Virus Infection. Cold Spring Harb Perspect Med. 2019; 9 (1). pii: a031674. DOI: 10.1101/cshperspect. a031674.

22. Liu D, Tan Q, Zhu J, Zhang Y, Xue Y, Song Y, et al. MicroRNA-33/33* inhibit the activation of MAVS through AMPK in antiviral innate immunity. Cell Mol Immunol. 2019. DOI: 10.1038/s41423-0190326-X.

23. Yang S, Harding AT, Sweeney C, Miao D, Swan G, Zhou C, et al. Control of antiviral innate immune response by protein geranylgeranylation. Sci Adv. 2019; 5 (5): eaav7999. DOI: 10.1126/sciadv.aav7999.

24. Maugeri N, Rovere-Querini P, Evangelista V, Covino C, Capobianco A, Bertilaccio MT, et al. Neutrophils phagocytose activated platelets in vivo: a phosphatidylserine, P-selectin and \{beta\}2 integrin-dependent cell clearance program. Blood. 2009; 113: 5254-65. DOI: 10.1182/blood-2008-09-180794.

25. Manfredi AA, Covino C, Rovere-Querini P, Maugeri N. Instructive influences of phagocytic clearance of dying cells on neutrophil extracellular trap generation. Clin Exp Immunol. 2015; 179 (1): 24-9. DOI: 10.1111/cei.12320.

26. Ma R, Xie R, Yu C, Si Y, Wu X, Zhao L, et al. Phosphatidylserinemediated platelet clearance by endothelium decreases platelet aggregates and procoagulant activity in sepsis. Sci Rep. 2017; 7 (1): 4978. DOI: 10.1038/s41598-017-04773-8.

27. Manfredi AA, Ramirez GA, Rovere-Querini P, Maugeri N. The Neutrophil's Choice: Phagocytose vs Make Neutrophil Extracellular Traps. Front Immunol. 2018; 9: 288. DOI: 10.3389/ fimmu.2018.00288. eCollection 2018.

28. Strumwasser A, Bhargava A, Victorino GP. Attenuation of Endothelial Phosphatidylserine Exposure Decreases IschemiaReperfusion Induced Changes in Microvascular Permeability. J Trauma Acute Care Surg. 2018; 84 (6): 838-46. DOI: 10.1097/ TA.0000000000001891.

29. Tong D, Yu M, Li G, Li T, Li J, Novakovic VA, et al. Phosphatidylserineexposing Blood and Endothelial Cells Contribute to the Hypercoagulable State in Essential Thrombocythemia Patients. Ann Hematol. 2018; 97 (4): 605-16. DOI: 10.1007/s00277-0183228-6.

30. Laridan E, Martinod K, De Meyer SF. Neutrophil Extracellular Traps in Arterial and Venous Thrombosis. Semin Thromb Hemost. 2019; 45 (1): 86-93. DOI: 10.1055/s-0038-1677040.

31. Li B, Liu Y, Hu T, Zhang Y, Zhang C, Li T, et al. Neutrophil Extracellular Traps Enhance Procoagulant Activity in Patients With Oral Squamous Cell Carcinoma. J Cancer Res Clin Oncol. 2019; 145 (7): 1695-707. DOI: 10.1007/s00432-019-02922-2.

32. Becker RC. COVID-19 Update: Covid-19-associated Coagulopathy. J Thromb Thrombolysis. 2020; 1-14. DOI: 10.1007/s11239-020-02134-3.

33. Barnes BJ, Adrover JM, Baxter-Stoltzfus A, Borczuk A, CoolsLartigue J, Crawford JM, et al. Targeting Potential Drivers of COVID-19: Neutrophil Extracellular Traps. J Exp Med. 2020; 217 (6): e20200652. DOI: 10.1084/jem.20200652.

34. Qin C, Zhou L, Hu Z, Zhang S, Yang S, Tao Y, et al. Dysregulation of Immune Response in Patients With COVID-19 in Wuhan, China Clin Infect Dis. 2020; ciaa248. DOI: 10.1093/cid/ciaa248.

35. Kazimirskii AN, Poryadin GV, Salmasi JM. The mechanisms of development of immunodeficiency in non-specific inflammation of infectious origin. Pathological physiology and experimental therapy. 2003; 3: 23. Russian. 
36. Poryadin GV, Salmasi JM, Kazimirskii AN. Activation markers of lymphocytes as indicators of dysregulation of the immune system during inflammation. Pathological physiology and experimental therapy. 2006; 1: 2-7. Russian.

37. Salmasi JM, Kazimirskii AN, Poryadin GV. The leading mechanisms of pathogenesis in inflammation of various origins. Russian Immunological Journal. 2019; 13-22 (2): 518-20. Russian.

38. Zhang L, Pang R, Xue X, Bao J, Ye S, Dai Y, et al. Anti-SARSCoV-2 Virus Antibody Levels in Convalescent Plasma of Six Donors Who Have Recovered From COVID-19 Aging (Albany NY). 2020; 12 (8): 6536-42. DOI: 10.18632/aging.103102.

39. Guo L, Ren L, Yang S, Xiao M, Chang D, Yang F, et al. Profiling Early Humoral Response to Diagnose Novel Coronavirus Disease (COVID-19). Clin Infect Dis. 2020; ciaa310. DOI: 10.1093/cid/ ciaa310.

40. Lee Y-L, Liao C-H, Liu P-Y, Cheng C-Y, Chung M-Y, Liu C-E, et al. Dynamics of anti-SARS-Cov-2 IgM and IgG Antibodies Among COVID-19 Patients. J Infect. 2020; S0163-4453(20)30230-9. DOI: 10.1016/j.jinf.2020.04.019.

41. Kazimirskii AN, Poryadin GV, Salmasi JM, Semenova LY. Endogenous regulators of the immune system (sCD100, malonic dialdehyde, and arginase). Bulletin of Experimental Biology and Medicine. 2018; 164 (5): 693-700. DOI: 10.1007/s10517-0184061-6.

42. Kazimirskii AN, Salmasi JM, Poryadin GV. Coordination of Innate and Adaptive Immunity Depending on Neutrophilic Extracellular Traps Formation. Austin J Clin Immunol. 2019; 6 (1): 1037.

43. Kazimirskii AN, Salmasi JM, Poryadin GV. Neutrophil extracellular traps regulate the development of innate and adaptive immune system. Russian Medical Review. 2020; 4 (1): 38-41. DOI: 10.32364/2587-6821-2020-4-1-38-41. Russian.

44. Imai K, Tabata S, Ikeda M, Noguchi S, Kitagawa Y, Matuoka M, et al. Clinical Evaluation of an Immunochromatographic lgM/ IgG Antibody Assay and Chest Computed Tomography for the Diagnosis of COVID-19. J Clin Virol. 2020; 128: 104393. DOI: 10.1016/j.jcv.2020.104393.

45. Hu Z, Song C, Xu C, Jin G, Chen Y, Xu X, et al. Clinical Characteristics of 24 Asymptomatic Infections With COVID-19 Screened Among Close Contacts in Nanjing, China. Sci China Life Sci. 2020; 63 (5): 706-11. DOI: 10.1007/s11427-020-1661-4

46. Baettig SJ, Parini A, Cardona I, Morand GB. Case Series of Coronavirus (SARS-CoV-2) in a Military Recruit School: Clinical Sanitary and Logistical Implications. BMJ Mil Health. 2020; DOI: 10.1136/bmjmilitary-2020-001482.

47. Rozières A, Viret C, Faure M. Autophagy in Measles Virus Infection. Viruses. 2017; 9 (12): 359. DOI: 10.3390/v9120359.

48. Mohamud Y, Shi J, Qu J, Poon T, Xue YC, Deng H, et al. Enteroviral Infection Inhibits Autophagic Flux via Disruption of the SNARE Complex to Enhance Viral Replication. Cell Rep. 2018; 22 (12): 3292-303. DOI: 10.1016/j.celrep.2018.02.090.

49. Lai JKF, Sam I-C, Verlhac P, Baguet J, Eskelinen E-L, Faure M, et

\section{Литература}

1. Cai X, Xu H, Chen ZJ. Prion-Like Polymerization in Immunity and Inflammation. Cold Spring Harb Perspect Biol. 2017; 9 (4). pii: a023580. DOI: 10.1101/cshperspect.a023580.

2. He X, Zhu Y, Zhang Y, Geng Y, Gong J, Geng J, et al. RNF34 functions in immunity and selective mitophagy by targeting MAVS for autophagic degradation. EMBO J. 2019. pii: e100978. DOI: 10.15252/embj.2018100978.

3. Cai X, Chen J, Xu H, Liu S, Jiang QX, Halfmann R, et al. Prion-like polymerization underlies signal transduction in antiviral immune defense and inflammasome activation. Cell. 2014; 156 (6): 12072. DOI: 10.1016/j.cell.2014.01.063.

4. Cai X, Xu H, Chen ZJ. Prion-Like Polymerization in Immunity and Inflammation. Cold Spring Harb Perspect Biol. 2017; 9 (4). pii: a023580. DOI: 10.1101/cshperspect.a023580.

5. Dutta M, Robertson SJ, Okumura A, Scott DP, Chang J, Weiss JM et al. A Systems Approach Reveals MAVS Signaling in Myeloid Cells as Critical for Resistance to Ebola Virus in Murine Models al. 2BC Non-Structural Protein of Enterovirus A71 Interacts With SNARE Proteins to Trigger Autolysosome Formation Viruses. 2017; 9 (7): 169. DOI: 10.3390/v9070169.

50. Peng H, Liu B, Yves TD, He Y, Wang S, Tang H, et al. Zika Virus Induces Autophagy in Human Umbilical Vein Endothelial Cells. Viruses. 2018; 10 (5): 259. DOI: 10.3390/v10050259.

51. Gratton R, Agrelli A, Tricarico PM, Brandão L, Crovella S. Autophagy in Zika Virus Infection: A Possible Therapeutic Target to Counteract Viral Replication. Int J Mol Sci. 2019; 20 (5): 1048. DOI: 10.3390/ijms20051048.

52. Blázquez A-B, Escribano-Romero E, Merino-Ramos T, Saiz J-C, Martín-Acebes MA. Infection With Usutu Virus Induces an Autophagic Response in Mammalian Cells. PLoS Negl Trop Dis. 2013; 7 (10): e2509. DOI: 10.1371/journal.pntd.0002509.

53. Lee N-R, Ban J, Lee N-J, Yi C-M, Choi J-Y, Kim H, et al. Activation of RIG-I-Mediated Antiviral Signaling Triggers Autophagy Through the MAVS-TRAF6-Beclin-1 Signaling Axis. Front Immunol. 2018 Sep 12; 9: 2096. DOI: 10.3389/fimmu.2018.02096.

54. Silva LM, Jung JU. Modulation of the Autophagy Pathway by Human Tumor Viruses. Semin Cancer Biol. 2013; 23 (5): 323-8. DOI: 10.1016/j.semcancer.2013.05.005.

55. Green DR, Llambi F. Cell Death Signaling Cold Spring Harb Perspect Biol. 2015; 7 (12): a006080. DOI: 10.1101/cshperspect. a006080.

56. Nishida K, Tamura A, Yui N. ER Stress-Mediated Autophagic Cell Death Induction Through Methylated $\beta$-Cyclodextrins-Threaded Acid-Labile Polyrotaxanes. J Control Release. 2018; 275: 20-31. DOI: 10.1016/j.jconrel.2018.02.010.

57. Wang $Y$, Jiang K, Zhang Q, Meng S, Ding C. Autophagy in Negative-Strand RNA Virus Infection. Front Microbiol. 2018; 9: 206. DOI: $10.3389 /$ fmicb.2018.00206.

58. Müller-Quernheim UC, Potthast L, Müller-Quernheim J, Zissel G. Tumor-cell Co-Culture Induced Alternative Activation of Macrophages Is Modulated by Interferons in Vitro. J Interferon Cytokine Res. 2012; 32 (4): 169-77. DOI: 10.1089/jir.2011.0020.

59. Tarique AA, Logan J, Thomas E, Holt PG, Sly PD, Fantino E. Phenotypic, Functional, and Plasticity Features of Classical and Alternatively Activated Human Macrophages. Am J Respir Cell Mol Biol. 2015; 53 (5): 676-88. DOI: 10.1165/rcmb.2015-0012OC.

60. Yang Y, Huang X, Chen S, Ma G, Zhu M, Yan F, Yu J. Resveratrol Induced Apoptosis in Human Gastric Carcinoma SGC-7901 Cells via Activation of Mitochondrial Pathway. Asia Pac J Clin Oncol. 2018; 14 (5): e317-e324. DOI: 10.1111/ajco.12841.

61. Wang D, Gao Z, Zhang X. Resveratrol Induces Apoptosis in Murine Prostate Cancer Cells via Hypoxia-Inducible Factor 1-alpha (HIF$1 \alpha$ )/Reactive Oxygen Species (ROS)/P53 Signaling. Med Sci Monit. 2018; 24: 8970-6. DOI: 10.12659/MSM.913290.

62. Li C, Hu W-L, Lu M-X, Xiao G-F. Resveratrol Induces Apoptosis of Benign Prostatic Hyperplasia Epithelial Cell Line (BPH-1) Through p38 MAPK-FOXO3a Pathway BMC Complement Altern Med. 2019; 19 (1): 233. DOI: 10.1186/s12906-019-2648-8.

of Infection. Cell Rep. 2017; 18 (3): 816-29. DOI: 10.1016/j. celrep.2016.12.069.

6. Hu Y, Dong X, He Z, Wu Y, Zhang S, Lin J, et al. Zika virus antagonizes interferon response in patients and disrupts RIGI-MAVS interaction through its CARD-TM domains. Cell Biosci. 2019; 9: 46. DOI: 10.1186/s13578-019-0308-9. eCollection 2019.

7. Hu X, Peng X, Lu C, Zhang X, Gan L, Gao Y, et al. Type I IFN expression is stimulated by cytosolic MtDNA released from pneumolysin-damaged mitochondria via the STING signaling pathway in macrophages. FEBS J. 2019. DOI: 10.1111/febs.15001.

8. Liu S, Cai X, Wu J, Cong Q, Chen X, Li T, et al. Phosphorylation of innate immune adaptor proteins MAVS, STING, and TRIF induces IRF3 activation. Science. 2015; 347 (6227): aaa2630. DOI: 10.1126/science.aaa2630.

9. Diner EJ, Burdette DL, Wilson SC, Monroe KM, Kellenberger CA Hyodo $\mathrm{M}$, et al. The innate immune DNA sensor cGAS produces a noncanonical cyclic dinucleotide that activates human STING. Cell 
Rep. 2013; 3 (5): 1355-61. DOI: 10.1016/j.celrep.2013.05.009.

10. Schwede F, Genieser HG, Rentsch A. The Chemistry of the Noncanonical Cyclic Dinucleotide 2'3'-cGAMP and Its Analogs. Handb Exp Pharmacol. 2017; 238: 359-84. DOl: 10.1007/164_2015_43.

11. Eaglesham JB, Pan Y, Kupper TS, Kranzusch PJ. Viral and metazoan poxins are cGAMP-specific nucleases that restrict cGAS-STING signalling. Nature. 2019; 566 (7743): 259-63. DOI: 10.1038/s41586-019-0928-6.

12. Oh DS, Kim TH, Lee HK. Differential Role of Anti-Viral Sensing Pathway for the Production of Type I Interferon - in Dendritic Cells and Macrophages Against Respiratory Syncytial Virus A2 Strain Infection. Viruses. 2019; 11 (1). pii: E62. DOI: 10.3390/ v11010062.

13. Goritzka M, Makris S, Kausar F, Durant LR, Pereira C, Kumagai Y, et al. Alveolar macrophage-derived type I interferons orchestrate innate immunity to RSV through recruitment of antiviral monocytes. J Exp Med. 2015 May 4; 212 (5): 699-714. DOI: 10.1084/jem.20140825.

14. Goritzka M, Pereira C, Makris S, Durant LR, Johansson C. T cell responses are elicited against Respiratory Syncytial Virus in the absence of signalling through TLRs, RLRs and IL-1R/LL-18R. Sci Rep. 2015 Dec 21; 5: 18533. DOI: 10.1038/srep18533.

15. Sturge CR, Benson A, Raetz M, Wilhelm CL, Mirpuri J, Vitetta ES, et al. TLR-independent neutrophil-derived IFN- $\gamma$ is important for host resistance to intracellular pathogens. Proc Natl Acad Sci USA. 2013; 110 (26): 10711-6. DOI: 10.1073/pnas.1307868110.

16. Kirsebom FCM, Kausar F, Nuriev R, Makris S, Johansson C. Neutrophil recruitment and activation are differentially dependent on MyD88/TRIF and MAVS signaling during RSV infection. Mucosal Immunol. 2019. DOI: 10.1038/s41385-019-0190-0.

17. Gonzalez-Quintial R, Nguyen A, Kono DH1, Oldstone MBA, Theofilopoulos AN, Baccala R. Lupus acceleration by a MAVSactivating RNA virus requires endosomal TLR signaling and host genetic predisposition. PLoS One. 2018; 13 (9): e0203118. DOI: 10.1371/journal.pone.0203118. eCollection 2018.

18. Lei Y, Moore CB, Liesman RM, O'Connor BP, Bergstralh DT, Chen ZJ, et al. MAVS-mediated apoptosis and its inhibition by viral proteins. PLoS One. 2009; 4 (5): e5466. DOI: 10.1371/journal. pone.0005466.

19. El Maadidi S, Faletti L, Berg B, Wenzl C, Wieland K, Chen ZJ, et al. A novel mitochondrial MAVS/Caspase-8 platform links RNA virus-induced innate antiviral signaling to Bax/Bak-independent apoptosis. J Immunol. 2014; 192 (3): 1171-83. DOI: 10.4049/ jimmunol.1300842.

20. Dong $W, L v H, L i C$, Liu Y, Wang C, Lin J, et al. MAVS induces a host cell defense to inhibit CSFV infection. Arch Virol. $2018 \mathrm{Jul}$; 163 (7): 1805-21. DOI: 10.1007/s00705-018-3804-z.

21. Hirai-Yuki A, Whitmire JK, Joyce M, Tyrrell DL, Lemon SM. Murine Models of Hepatitis A Virus Infection. Cold Spring Harb Perspect Med. 2019; 9 (1). pii: a031674. DOI: 10.1101/cshperspect. a031674.

22. Liu D, Tan Q, Zhu J, Zhang Y, Xue Y, Song Y, et al. MicroRNA-33/33* inhibit the activation of MAVS through AMPK in antiviral innate immunity. Cell Mol Immunol. 2019. DOI: 10.1038/s41423-0190326-X.

23. Yang S, Harding AT, Sweeney C, Miao D, Swan G, Zhou C, et al. Control of antiviral innate immune response by protein geranylgeranylation. Sci Adv. 2019; 5 (5): eaav7999. DOI: 10.1126/sciadv.aav7999.

24. Maugeri N, Rovere-Querini P, Evangelista V, Covino C, Capobianco A, Bertilaccio MT, et al. Neutrophils phagocytose activated platelets in vivo: a phosphatidylserine, P-selectin and \{beta\}2 integrin-dependent cell clearance program. Blood. 2009; 113: 5254-65. DOI: 10.1182/blood-2008-09-180794.

25. Manfredi AA, Covino C, Rovere-Querini P, Maugeri N. Instructive influences of phagocytic clearance of dying cells on neutrophil extracellular trap generation. Clin Exp Immunol. 2015; 179 (1): 24-9. DOI: 10.1111/cei.12320.

26. Ma R, Xie R, Yu C, Si Y, Wu X, Zhao L, et al. Phosphatidylserinemediated platelet clearance by endothelium decreases platelet aggregates and procoagulant activity in sepsis. Sci Rep. 2017; 7 (1): 4978. DOI: 10.1038/s41598-017-04773-8.
27. Manfredi AA, Ramirez GA, Rovere-Querini P, Maugeri N. The Neutrophil's Choice: Phagocytose vs Make Neutrophil Extracellular Traps. Front Immunol. 2018; 9: 288. DOI: 10.3389/ fimmu.2018.00288. eCollection 2018.

28. Strumwasser A, Bhargava A, Victorino GP. Attenuation of Endothelial Phosphatidylserine Exposure Decreases IschemiaReperfusion Induced Changes in Microvascular Permeability. J Trauma Acute Care Surg. 2018; 84 (6): 838-46. DOI: 10.1097/ TA.0000000000001891.

29. Tong D, Yu M, Li G, Li T, Li J, Novakovic VA, et al. Phosphatidylserineexposing Blood and Endothelial Cells Contribute to the Hypercoagulable State in Essential Thrombocythemia Patients. Ann Hematol. 2018; 97 (4): 605-16. DOI: 10.1007/s00277-0183228-6.

30. Laridan E, Martinod K, De Meyer SF. Neutrophil Extracellular Traps in Arterial and Venous Thrombosis. Semin Thromb Hemost. 2019; 45 (1): 86-93. DOI: 10.1055/s-0038-1677040.

31. Li B, Liu Y, Hu T, Zhang Y, Zhang C, Li T, et al. Neutrophil Extracellular Traps Enhance Procoagulant Activity in Patients With Oral Squamous Cell Carcinoma. J Cancer Res Clin Oncol. 2019; 145 (7): 1695-707. DOI: 10.1007/s00432-019-02922-2.

32. Becker RC. COVID-19 Update: Covid-19-associated Coagulopathy. J Thromb Thrombolysis. 2020; 1-14. DOI: 10.1007/s11239-020-02134-3.

33. Barnes BJ, Adrover JM, Baxter-Stoltzfus A, Borczuk A, CoolsLartigue J, Crawford JM, et al. Targeting Potential Drivers of COVID-19: Neutrophil Extracellular Traps. J Exp Med. 2020; 217 (6): e20200652. DOI: 10.1084/jem.20200652.

34. Qin C, Zhou L, Hu Z, Zhang S, Yang S, Tao Y, et al. Dysregulation of Immune Response in Patients With COVID-19 in Wuhan, China Clin Infect Dis. 2020; ciaa248. DOI: 10.1093/cid/ciaa248.

35. Казимирский А. Н., Порядин Г. В., Салмаси Ж. М. Механизмы развития иммунодефицита при неспецифическом воспалении инфекционного генеза. Патологическая физиология и экспериментальная терапия. 2003; 3: 23.

36. Порядин Г. В., Салмаси Ж. М., Казимирский А. Н. Активационные маркеры лимфоцитов как показатели дизрегуляции иммунной системы при воспалении. Патологическая физиология и экспериментальная терапия. 2006; 1: 2-7.

37. Салмаси Ж. М., Казимирский А. Н., Порядин Г. В. Ведущие механизмы патогенеза при воспалении различного генеза. Русский иммунологический журнал. 2019; 13-22 (2); 518-20.

38. Zhang L, Pang R, Xue X, Bao J, Ye S, Dai Y, et al. Anti-SARSCoV-2 Virus Antibody Levels in Convalescent Plasma of Six Donors Who Have Recovered From COVID-19 Aging (Albany NY). 2020; 12 (8): 6536-42. DOI: 10.18632/aging.103102.

39. Guo L, Ren L, Yang S, Xiao M, Chang D, Yang F, et al. Profiling Early Humoral Response to Diagnose Novel Coronavirus Disease (COVID-19). Clin Infect Dis. 2020; ciaa310. DOI: 10.1093/cid/ ciaa310.

40. Lee Y-L, Liao C-H, Liu P-Y, Cheng C-Y, Chung M-Y, Liu C-E, et al. Dynamics of anti-SARS-Cov-2 IgM and lgG Antibodies Among COVID-19 Patients. J Infect. 2020; S0163-4453(20)30230-9. DOI: 10.1016/j.jinf.2020.04.019.

41. Казимирский А. Н., Порядин Г. В., Салмаси Ж. М., Семенова Л. Ю. Эндогенные регуляторы иммунной системы (sCD100, малоновый диальдегид, аргиназа). Бюллетень экспериментальной биологии и медицины. 2017; 164 (11): 652-60.

42. Kazimirskii AN, Salmasi JM, Poryadin GV. Coordination of Innate and Adaptive Immunity Depending on Neutrophilic Extracellular Traps Formation. Austin J Clin Immunol. 2019; 6 (1): 1037.

43. Казимирский А. Н., Салмаси Ж. М., Порядин Г. В. Нейтросильные экстраклеточные ловушки - регуляторы формирования врожденного и адаптивного иммунитета. РМЖ. Медицинское обозрение. 2020; 1: 38-41. DOI: 10.32364/2587-6821-2020-4-1-38-41.

44. Imai K, Tabata S, Ikeda M, Noguchi S, Kitagawa Y, Matuoka M, et al. Clinical Evaluation of an Immunochromatographic IgM/ IgG Antibody Assay and Chest Computed Tomography for the Diagnosis of COVID-19. J Clin Virol. 2020; 128: 104393. DOI: 10.1016/j.jcv.2020.104393. 
45. Hu Z, Song C, Xu C, Jin G, Chen Y, Xu X, et al. Clinical Characteristics of 24 Asymptomatic Infections With COVID-19 Screened Among Close Contacts in Nanjing, China. Sci China Life Sci. 2020; 63 (5): 706-11. DOI: 10.1007/s11427-020-1661-4.

46. Baettig SJ, Parini A, Cardona I, Morand GB. Case Series of Coronavirus (SARS-CoV-2) in a Military Recruit School: Clinical, Sanitary and Logistical Implications. BMJ Mil Health. 2020; DOI: 10.1136/bmjmilitary-2020-001482.

47. Rozières A, Viret C, Faure M. Autophagy in Measles Virus Infection. Viruses. 2017; 9 (12): 359. DOI: 10.3390/v9120359.

48. Mohamud Y, Shi J, Qu J, Poon T, Xue YC, Deng H, et al. Enteroviral Infection Inhibits Autophagic Flux via Disruption of the SNARE Complex to Enhance Viral Replication. Cell Rep. 2018; 22 (12): 3292-303. DOl: 10.1016/j.celrep.2018.02.090.

49. Lai JKF, Sam I-C, Verlhac P, Baguet J, Eskelinen E-L, Faure M, et al. 2BC Non-Structural Protein of Enterovirus A71 Interacts With SNARE Proteins to Trigger Autolysosome Formation Viruses. 2017; 9 (7): 169. DOI: 10.3390/v9070169.

50. Peng H, Liu B, Yves TD, He Y, Wang S, Tang H, et al. Zika Virus Induces Autophagy in Human Umbilical Vein Endothelial Cells. Viruses. 2018; 10 (5): 259. DOI: 10.3390/v10050259.

51. Gratton R, Agrelli A, Tricarico PM, Brandão L, Crovella S. Autophagy in Zika Virus Infection: A Possible Therapeutic Target to Counteract Viral Replication. Int J Mol Sci. 2019; 20 (5): 1048. DOI: 10.3390/ijms20051048.

52. Blázquez A-B, Escribano-Romero E, Merino-Ramos T, Saiz J-C, Martín-Acebes MA. Infection With Usutu Virus Induces an Autophagic Response in Mammalian Cells. PLoS Negl Trop Dis. 2013; 7 (10): e2509. DOI: 10.1371/journal.pntd.0002509.

53. Lee N-R, Ban J, Lee N-J, Yi C-M, Choi J-Y, Kim H, et al. Activation of RIG-I-Mediated Antiviral Signaling Triggers Autophagy Through the MAVS-TRAF6-Beclin-1 Signaling Axis. Front Immunol. 2018 Sep 12; 9: 2096. DOI: 10.3389/fimmu.2018.02096.
54. Silva LM, Jung JU. Modulation of the Autophagy Pathway by Human Tumor Viruses. Semin Cancer Biol. 2013; 23 (5): 323-8. DOI: 10.1016/j.semcancer.2013.05.005

55. Green DR, Llambi F. Cell Death Signaling Cold Spring Harb Perspect Biol. 2015; 7 (12): a006080. DOI: 10.1101/cshperspect. a006080.

56. Nishida K, Tamura A, Yui N. ER Stress-Mediated Autophagic Cell Death Induction Through Methylated $\beta$-Cyclodextrins-Threaded Acid-Labile Polyrotaxanes. J Control Release. 2018; 275: 20-31. DOI: 10.1016/j.jconrel.2018.02.010.

57. Wang $Y$, Jiang K, Zhang Q, Meng S, Ding C. Autophagy in Negative-Strand RNA Virus Infection. Front Microbiol. 2018; 9: 206. DOI: $10.3389 /$ fmicb.2018.00206.

58. Müller-Quernheim UC, Potthast L, Müller-Quernheim J, Zissel G. Tumor-cell Co-Culture Induced Alternative Activation of Macrophages Is Modulated by Interferons in Vitro. J Interferon Cytokine Res. 2012; 32 (4): 169-77. DOI: 10.1089/jir.2011.0020.

59. Tarique AA, Logan J, Thomas E, Holt PG, Sly PD, Fantino E. Phenotypic, Functional, and Plasticity Features of Classical and Alternatively Activated Human Macrophages. Am J Respir Cell Mol Biol. 2015; 53 (5): 676-88. DOI: 10.1165/rcmb.2015-0012OC.

60. Yang Y, Huang X, Chen S, Ma G, Zhu M, Yan F, Yu J. Resveratrol Induced Apoptosis in Human Gastric Carcinoma SGC-7901 Cells via Activation of Mitochondrial Pathway. Asia Pac J Clin Oncol. 2018; 14 (5): e317-e324. DOI: 10.1111/ajco.12841.

61. Wang D, Gao Z, Zhang X. Resveratrol Induces Apoptosis in Murine Prostate Cancer Cells via Hypoxia-Inducible Factor 1-alpha (HIF-1 $\alpha$ )/Reactive Oxygen Species (ROS)/P53 Signaling. Med Sci Monit. 2018; 24: 8970-6. DOI: 10.12659/MSM.913290.

62. Li C, Hu W-L, Lu M-X, Xiao G-F. Resveratrol Induces Apoptosis of Benign Prostatic Hyperplasia Epithelial Cell Line (BPH-1) Through p38 MAPK-FOXO3a Pathway BMC Complement Altern Med. 2019; 19 (1): 233. DOI: 10.1186/s12906-019-2648-8. 